ANDRZEJ STROYNOWSKI

AKademia im. Jana DŁugosza w Częstochowie

\title{
Czasy saskie w opiniach epoki stanisławowskiej (po 1772 r.)
}

Epoka saska nadal budzi spore zainteresowanie ${ }^{1}$, a w epoce stanisławowskiej musiało być to znacznie wyraźniejsze, gdyż jeszcze doskonale pamiętano saskie panowanie, które wyryło piętno na sposobie myślenia społeczeństwa polskiego, co uwidaczniało się chociażby przy ocenianiu bieżacych wydarzeń oraz wpływało na kształt podejmowanych decyzji politycznych i towarzyszacej im argumentacji. Szczególnie w pierwszych latach po elekcji Stanisława Augusta żywe były wspomnienia saskiego panowania, które zresztą zakończyło się nie w wyniku samodzielnej decyzji społeczeństwa polskiego, lecz na skutek interwencji Katarzyny II na rzecz jej protegowanego ${ }^{2}$. W tym czasie jednak ta popularność dynastii saskiej nie wiązała się $\mathrm{z}$ odpowiednim zaangażowaniem dworu drezdeńskiego i jego sojuszników. O porażce wettyńskiej w czasie ostatniej wolnej elekcji zadecydować też miało niedołęstwo przywódców stronnictwa saskiego, co wyrażało się w utrzymującej się opinii, że po śmierci Augusta III „saska dynastia miała jeszcze wielu przyjaciół w Polsce i utrzymuja, że gdyby w obozie pod Wola Potoccy się

1 J. S t a s z e w ski, Unia polsko-saska z perspektywy trzystu lat, [w:] Rzeczpospolita wielu narodów i jej tradycje. Materiały z konferencji "Trzysta lat od poczatku unii polsko-saskiej. Rzeczpospolita wielu narodów i jej tradycje”, Kraków 15-17 IX 1997 r., red. A.K. Link-Lenczowski, M. Markiewicz, Kraków 1999, s. 1521.

2 J. G i e r ow ski, Rzeczypospolita Obojga Narodów. Kilka uwag o roli unii personalnej $w$ dziejach Polski nowożytnej, [w:] i d e m, Na szlakach Rzeczypospolitej $w$ nowożytnej Europie, red. A.K. Link-Lenczowski, Kraków 2008, s. 94. 
do szabel rzucili, Poniatowski obranym by nie był" ${ }^{3}$. Napięcie elekcyjne było jednak tylko epizodem w porównaniu $z$ okresem konfederacji radomskiej i barskiej, gdy oczy wszystkich przeciwników Stanisława Augusta zwracały się ku Dreznu. Wówczas też Saksonia zyskała najwięcej zwolenników, wiązano $z$ nią największe nadzieje, najszczodrzej byli tam obdarowywani polscy emigranci, jak wreszcie najżywiej interesowano się rodziną elektorska. W tym też okresie sascy zwolennicy spod „barskich znaków” skupiali nie tylko zacofanych magnatów i szlachtę, ale też licznych przedstawicieli oświeconych elit, tworzacych programy naprawy Rzeczypospolitej4. To apogeum wzajemnych zainteresowań zakończyło się wraz z pierwszym rozbiorem Rzeczypospolitej ogólnym zniechęceniem społeczeństwa szlacheckiego do dotychczasowych przywódców i do saskiej tradycji, co jest dokładnie przedstawiane w literaturze przedmiotu ${ }^{5}$. Okres pierwszego dziesięciolecia panowania ostatniego króla, jako zamknięty i przebadany, można tu pominąć, by skupić się na czasach po pierwszym rozbiorze Rzeczypospolitej, gdy dokonywały się przemiany poglądów politycznych, gdy zmieniały się oceny saskiego panowania, którego żywa pamięć powoli wygasała i była zastępowana przez sądy, które wynikały bardziej $z$ bieżacych potrzeb politycznych niż z rzeczywistej znajomości dawnych realiów.

Oczywiście można przyjąć, że w jakimś stopniu wiązało się to $z$ powolnym przechodzeniem od "sentymentów" do „resentymentów"

${ }^{3}$ L. Enge strö m, Pamiętniki, [w:] Polska stanisławowska w oczach cudzoziemców, oprac. W. Zawadzki, Warszawa 1963, t. II, s. 126.

${ }_{4}^{4}$ Okres ten jest bodaj najlepiej i najpełniej omówiony w literaturze przedmiotu, aczkolwiek ostatnio zainteresowanie nim wyraźnie zmalało. Por. W. K o n o p c zyńs ki, Konfederacja barska, t. I-II, Warszawa 1991; A. Kra u s har, Ksiaże Repnin i Polska, Warszawa 1900; J. M i chals ki, Gdyby nami rzadzity kobiety. (Poglady Amalii Mniszchowej w reforme Rzeczypospolitej), [w:] Wiek XVIII. Polska $i$ świat. Ksiega poświęcona Bogusławowi Leśnodorskiemu, Warszawa 1974, s. 141153; i d e m, Propaganda konserwatywna $w$ walce $z$ reforma $w$ poczatkach panowania Stanisława Augusta, „Przegląd Historyczny” 1952, t. XLIII, z. 3-4, s. 536562; E. R o s tw o r ow s ki, Ostatni król Rzeczypospolitej. Geneza i upadek Konstytucji 3 Maja, Warszawa 1958; W. Szczygielski, Konfederacja barska $w$ Wielkopolsce 1768-1770, Warszawa 1970.

5 W. Ko n o p czyńs ki, op. cit.; W. Szczygielski, op. cit.; J. Micha $1-$ s ki, Schyłek konfederacji barskiej, Wrocław-Warszawa-Kraków 1970; A.M. S t a s i a k, Patriotyzm $w$ myśli konfederatów barskich, Lublin 2005; J. S t a s z e ws k i, Polacy w osiemnastowiecznym Dreźnie, Wrocław 1986. 
bądź też nawet uznać, iż był to wynik różnic pokoleniowych ${ }^{6}$. Dominacja "sentymentów" widoczna jest jednak tylko w literaturze pamiętnikarskiej. Odnosi się to nawet do Marcina Matuszewicza, który pomimo porzucenia sprawy saskiej i zwiąania się z Czartoryskimi, dobrze wspominał Augusta III jako władcę pozwalającego na bogacenie się poddanych, na rządy swoich ministrów, bez podejmowania prób wzmacniania swojej pozycji ${ }^{7}$. Często zreszta nie była to tęsknota za systemem rząóow saskich i panowaniem Augusta III w Polsce, lecz za okresem długotrwałego pokoju i zamożności całego społeczeństwa, a szlachty w szczególności, która jednak opłacić to miała zgubnym nałogiem pijaństwa, potępianym przez moralistów ${ }^{8}$. Jest rzeczą ciekawa, że nawet ludzie prezentujący nowe wartości oświeceniowe i generalnie przeciwni rządom saskim, dostrzegali pewne walory Augusta III, akcentując jego oddanie rodzinie i rzetelność, czy widząc w nim - przynajmniej zewnętrzne - uosobienie monarszej powagi i przywiązania do sarmatyzmu, porównywane $z$ krytycznie oceniana $w$ tym względzie postawa Stanisława Augusta9. Były to jednak opinie, których nie zamierzano publikować i świadczyły one tylko o prywatnych przekonaniach, którymi nie planowano się dzielić.

Inne spojrzenie na saska przeszłość prezentowano na forum sejmowym i na sejmikach, a wyrażane tam opinie formułowane były zazwyczaj w zależności od bieżących wydarzeń politycznych. Sądy

$6 \mathrm{~J}$. Grobis, Czasy saskie $w$ sentymentach $i$ resentymentach oświeconych, [w:] Między barokiem a oświeceniem. Nowe spojrzenie na czasy saskie, red. K. Stasiewicz, S. Achremczyk, Olsztyn 1996, s. 33-45.

7 M. M a tu s z ew i c z, Diariusz życia mego, oprac. B. Królikowski, komentarz Z. Zielińska, t. II, Warszawa 1986, s. 399-400. Jeszcze wyraźniej żal ze śmierci Augusta III i tęsknotę za odchodząca dynastią wrażał były uczestnik konfederacji barskiej, głoszac: „nie miała Polska i nie będzie miała tak dobrego, tak wspaniałego i tak hojnego króla”. Por. J. Kitowicz, Pamiętniki, czyli historia polska, oprac. P. Matuszewska, Z. Lewinówna, Warszawa 1971, s. 30 oraz 40, 86. $Z$ tą opinia Kitowicza nie można się jednak zgodzić. Por. J. Gi e rowski, Rzeczypospolita Obojga Narodów..., s. 95.

8 J. Kitowicz, Opis obyczajów za panowania Augusta III, wyd. III, oprac. R. Pollak, Wrocław 1970, s. 378; A. M o s z c z eń s ki, Pamiętnik do historii polskiej $w$ ostatnich latach panowania Augusta III i pierwszych Stanisława Poniatowskiego, Kraków 1888, s. 1.

9 J. K o s s a k o w s k i, Pamiętniki Józefa Kossakowskiego biskupa inflanckiego 1738-1788, wyd. A. Darowski, Warszawa 1891, s. 20; K. K oź m i a n, Pamiętniki obejmujace wspomnienia od r. 1780 do r. 1815, t. I, Poznań 1858, s. 137. 
wypowiadane publicznie kształtowały się pod wpływem tragicznych doświadczeń konfederacji barskiej, które odarły społeczeństwo ze złudzeń i zmusiły do szukania nowych możliwości życia i działania ${ }^{10}$. Doszło wówczas zwłaszcza do zerwania $z$ tradycja heroizmu wojennego, zastapionego dość powszechnym pragmatyzmem politycznym, który skłaniał nawet niedawnych konfederatów do podjęcia współpracy $z$ dworem, co szczególnie wyraźne było w Wielkopolsce ${ }^{11}$. Wyrazem tej postawy stało się powszechne głoszenie po-

10 Według Jerzego Michalskiego: „Lekcja pierwszego rozbioru uczyła pesymizmu i ostrożności. Najbliższe po nim lata nie stworzyły też okazji do odrodzenia się koncepcji politycznych barzan, choć wiele $z$ ich ducha przejęła tzw. opozycja magnacka $z$ lat 1775-1788. W czasie konfliktu austriacko-pruskiego w latach 17781779 polscy "aktywiści" polityczni znaleźli się u boku Rosji, a pod przewodem Stanisława Augusta. Miejsce dla barzan było jedynie po stronie Austrii, ale pamięć zdrady w 1772 r. dyskredytowała w oczach konfederatów politykę dworu wiedeńskiego [...] Dopiero rok 1787 stworzył realne warunki do czucia i myślenia kategoriami jeśli nie barskimi, to zbliżonymi do nich. Odrodziła się orientacja turecka, znów szukano w Europie kandydatów do polskiego tronu, którzy by zagwarantowali niepodległość i niezależność Rzeczypospolitej..." Cyt. za: J. Michalski, Schyłek konfederacji barskiej..., s. 192. Por. niezwykle istotne uwagi o zmianie pogladów społeczeństwa pod wpływem klęski konfederacji barskiej zarówno w zakresie umacniania antymagnatyzmu, jak i narodzin tendencji regalistycznych, autorstwa J. M a c i ej ew sk i e g o, Geneza $i$ charakter ideologii republikanów 1767-1775, „Archiwum Historii Filozofii i Myśli Społecznej” 1971, t. XVII, s. 45-52; id e m, Wstęp, [w:] Literatura barska (Antologia), oprac. J. Maciejewski, Wrocław 1976, s. LXXXIV. O dokonujacym się przełomie świadomościowym i kulturalnym por. też M. K1 i m o w i c z, Oświecenie, Warszawa 1972; E. R o s t w o r o w s k i, Sprawa aukcji wojska na tle sytuacji politycznej przed Sejmem Czteroletnim, Warszawa 1957; W. S z c zy gi e ls ki, Przełomy w polskiej kulturze politycznej $w$ drugiej połowie XVIII w., „Acta Universitatis Lodziensis”, Folia historica 22, 1985, s. 21-43.

11 J. F a bre, Stanislas Auguste Poniatowski et l'Europe de Lumières. Ėtude de cosmopolitisme, Paris 1952 s. 562-563; A. Li ty ń s ki, Sejmiki jako instytucja demokracji szlacheckiej 1764-1793. Tradycja - mity - nowości - utopia, [w:] Parlamentaryzm i prawodawstwo przez wieki. Prace dedykowane Prof. Stanisławowi Płazie $w$ siedemdziesiata rocznice urodzin, red. J. Malec, W. Uruszczak, Kraków 1999, s. 85; S. Mikulski, Walka o język polski $w$ czasach Oświecenia, [w:] i d e m, Ze studiów nad Oświeceniem. Zagadnienia i fakty, Warszawa 1956, s. 6465; A. S t r o y n o w s k i, Oblicze polityczne Wielkopolski w epoce stanisławowskiej, [w:] Regiony: Polska - Europa - świat, red. A. Stępień-Kuczyńska, K. DośpiałBorysiak, Torun 2009, s. 43-60; id e m, Postawy polityczne elit Wielkopolski $w$ epoce stanisławowskiej (województwa poznańskie, kaliskie i gnieźnieńskie), [w:] Między barokiem a oświeceniem. Staropolski regionalizm, red. S. Achremczyk, Olsztyn 2008, s. 203-214. 
parcia dla królewskich haseł budowy podstaw rozwoju gospodarczego i kulturalnego oraz sprawnego funkcjonowania państwa, nawet $\mathrm{w}$ jego okrojonych granicach. Towarzyszyło temu wyrażanie krytycznej oceny czasów saskich, które obarczono odpowiedzialnościa za rozbiór, za zacofanie i niedowład organizacyjny państwa, co miało uzasadniać i tym silniej podkreślać dokonujący się oświeceniowy postęp stanisławowskiego „królestwa rozumu” ${ }^{12}$. To przekonanie najdobitniej wyraził w lapidarnie sformułowanej opinii Józef Wybicki: „Za Augustów przejęliśmy tyle zła, tylko zarazę wieku, światła jego nie doszły nas łaski"13. W krytycznych ocenach epoki saskiej przodowali zwłaszcza działacze Komisji Edukacji Narodowej czy też szerzej ujmując - ludzie pióra, zestawiający saskie rozprzężenie, prywatę i pijaństwo $z$ przełomem umysłowym i odrodzeniem dokonujacym się po I rozbiorze ${ }^{14}$. Głoszac hasła pracy organicznej, wina za upadek kraju obarczali oni czasy saskie, których zgubna kontynuacja miała być konfederacja barska, z jej brakiem zrozumienia realiów polityki międzynarodowej i poczucia zagrożenia zewnętrznego, a ówczesne szukanie obcej protekcji doprowadziło według nich do rozbioru. W opinii owych oświeceniowych dzia-

12 Zasadniczą rolę w kształtowaniu tych postaw odgrywał oczywiście sam król, który również w swoich spisywanych później pamiętnikach negatywnie oceniał saskie panowanie, dając wręcz szyderczy obraz życia sejmikowego w opowieści o swoich zabiegach o poselstwo $z$ Łomży (słynna postać Glinki), jak też jednoznacznie krytykujac cechy Augusta III: „pycha i lenistwo były dwiema największymi wadami Augusta III". Por. Stanisław August Poniatowski, Pamiętniki, oprac. Z. Góralski, t. I, Warszawa 1995, s. 54, 107-112.

13 J. W y b i cki, Pamiętniki... senatora Królestwa Polskiego, cz. I, Warszawa 1905, s. 144.

14 Skrajnie negatywny obraz czasów saskich pozostawili Hugo Kołłątaj i Józef Wybicki, krytykując zwłaszcza szkolnictwo jezuickie. Por. H. Kołła taj, Stan oświecenia $w$ Polszcze $w$ ostatnich latach panowania Augusta III (1750-1764), Warszawa 1905, s. 132-133; J. W y b i c k i, Życie moje, Warszawa 1958, s. 9, 91, 139; A. M os z czeń ski, op. cit., s. 1. Należy zauważyć, że zarzuty pod adresem szkolnictwa jezuickiego $z$ końcowego okresu panowania Wettynów nie były już uzasadnione, a wynikały $z$ polemicznych celów, przyświecajacych tym działaczom KEN, którzy celowo zapominali o dokonaniach epoki saskiej, o wyjątkowej liczbie szkół i kolegiów o bardzo różnym charakterze i programach z reformą Stanisława Konarskiego na czele. Por. A.S. K a m iń s k i, Imponderabilia społeczeństwa obywatelskiego Rzeczypospolitej Wielu Narodów, [w:] Rzeczpospolita wielu narodów..., s. 57-58; K. Puchowski, Model kształcenia szlachty w kolegiach jezuickich, [w:] Między barokiem a oświeceniem..., s. 100-104. 
łaczy politycznych tradycja saskiego panowania miała po raz ostatni zatriumfować nawet jeszcze w czasie pierwszego sejmu rozbiorowego, wyrażając się zaprzedaniem rosyjskim interesom i zwycięstwem najniższych instynktów kliki marszałka Adama Ponińskiego, która przyznawała sobie nagrody, tytuły a oddawała się pijaństwu i „wyuzdanym namiętnościom”15.

Były to więc opinie o charakterze czysto propagandowym. Jednocześnie, po załamaniu się unii personalnej, nie było specjalnych warunków do pogłębienia wśród szerokich kręgów społeczeństwa wiedzy o aktualnych losach Saksonii. Dominowała bowiem tendencja do traktowania jej jako jednego $z$ wielu państw europejskich, $\mathrm{w}$ dodatku niezbyt interesujacego. Przynajmniej taki wniosek nasuwa się $z$ lektury ówczesnej prasy, która równa miarę przykładała do wydarzeń w Saksonii, jak i np. w znacznie odleglejszej Sardynii. Dominowały przy tym wiadomości $z$ najwyższych sfer dworskich, co było zreszta przydatne dla polskiej magnaterii, zwłaszcza w trakcie jej zagranicznych wojaży. $Z$ racji swej jałowości informacje zamieszczane $\mathrm{w}$ oficjalnych wydawnictwach nie miały większego znaczenia ${ }^{16}$. Znaczenie ciekawsze były wówczas popularne gazetki pisane. One jednak też tylko w minimalnym stopniu odnotowywały zagadnienia międzynarodowe, cała uwage skupiajac na plotkach dworskich, interesujących ogół społeczeństwa. Nic też dziwnego, że - raczej senny wówczas - dwór drezdeński nie budził większego zainteresowania, co znalazło wyraz w umieszczeniu przez cały $1782 \mathrm{r}$. tylko jednej wzmianki o Saksonii - o narodzinach Marii Augusty Nepomuceny (i to $z$ przekręconą wersją imienia) ${ }^{17}$. Czasem tylko

15 J.U. Ni e m c e wi c z, Pamiętniki czasów moich, wyd. J. Dihm, t. I, Warszawa 1957, s. 69 . $Z$ taka ocena przyczyn rozbioru, jako odpowiadajaca zasadniczym celom rosyjskiej i pruskiej propagandy, polemizował W. Zajewski, Czy konfederacja barska była zasadnicza przyczyna pierwszego rozbioru Polski, [w:] Oświeceni wobec rozbiorów Polski, red. J. Grobis, Łódź 1998, s. 6-14.

16 Ten jednoznacznie plotkarsko-dworski charakter miały informacje ukazujace się w „Gazecie Warszawskiej”, jak i w popularnych wówczas kalendarzach czy seriarzach politycznych. Były to przy tym najłatwiej dostępne źródła wiadomości. Wyjątkiem były analizy stanu gospodarki Saksonii, zamieszczone przez księdza Piotra Świtkowskiego, który dostrzegał bardzo dobry stan rzemiosła saskiego, rozwijajacego się dzięki pokojowej polityce elektora: Obszerność, ludność, dochody, rzady i inne osobliwości Saksonii, „Pamiętnik Historyczno-Polityczny”, III 1784, s. 222-223.

17 T. O s trow s ki, Poufne wieści $z$ oświeconej Warszawy, oprac. R. Kaleta, Wrocław 1972, s. 140. O roli gazetek pisanych, zasięgu i oddziaływaniu oraz krę- 
spisywano relacje $z$ podróży po Saksonii, z których najciekawsza pozostawił - nie udostępniając jej jednak szerszemu gronu czytelników ani praktycznie nie wykorzystując - królewski bratanek Stanisław Poniatowski, skupiając się głównie na gospodarce, zabytkach architektury i opisach miejsc sławnych bitew ${ }^{18}$. W sumie znajomość saskich realiów, głównie gospodarczych, była nawet niezła, ale ograniczała się do wąskiej elity. W przypadku mas natomiast wiedza o współczesnej Saksonii była nader mglista i w rezultacie ograniczała się właściwie do samej tradycji panowania saskiego w Polsce.

W efekcie przez prawie szesnaście lat (1772-1788) przeważała tendencja do potępiania saskiej przeszłości, przeciwstawianej postępowi dokonujacemu się pod panowaniem Stanisława Augusta. Co przy tym ciekawe, ten nurt rozważań zapoczątkował tak konsekwentny w swym antymonarchizmie Kazimierz Nestor Sapieha, który $z$ potępieniem przeszłości wystapił jeszcze w 1778 r., stwierdzając: „po sześćdziesiąt sześcioletnim gnuśnym nierządzie następcy okrutnych zamieszań [...] jak po stu sześćdziesiąt dwuletnim cudzoziemskim, dwudziesto ośmiu laty tylko przerwanym panowaniu, doczekała się na koniec Piasta rządu, doczekanie wolnej swego współziomka, cnota tylko i rozumem celującego Elekcji [...] Nie zawiodła się Polska w swoim mniemaniu, bo odmieniła zaraz postać Króla; odmianę rząd wział miejsce nierządu, sprawiedliwość w swoje weszła karby, słuszne nagrody wzbudziły duch pracy, ustanowienie Szkoły Rycerskiej przez tylu nam Królów próżno obiecywane, podało młodzi doskonalenia się sposób, porządek Kraju, nauki, rzemiosła, wszystko kwitło, wszystko najpomyślniejsza przyszłościa serca cieszyło"19. Było to oczywiście starannie przygotowane pochlebstwo, niekoniecznie zgodne $z$ poglądami mówcy, lecz niewątpliwie wygłaszając je liczył się on $z$ odbiorcami, którzy takiego właśnie wywodu

gu autorów por. A. Bułówn a, Katalog gazetek pisanych z XVIII wieku w zbiorach Biblioteki Zakładu Narodowego im. Ossolińskich, Wrocław 1969.

18 S. Po n i a tow ski, Stanisława Poniatowskiego Diariusz podróży $w$ roku $1784 w$ kraje niemieckie przedsięwziętej, wyd. J. Wijaczka, Kielce 2002, s. 115157. Głównym celem podróży Poniatowskiego do Saksonii były manufaktury w Herrenhutt.

19 K.N. S a p i e h a, Mowa... $z$ doniesieniem o jadnostaynym obraniu Marszatka Sejmowego... 6 X 1778, [w:] Zbiór mów różnych. Mowy seymowe 1778, Poznań 1779 , k. nlb. Przy ocenie treści mowy należy pamiętać o wyjątkowo uroczystym charakterze tego wystapienia. 
musieli się spodziewać czy wręcz go oczekiwać. Ten styl wypowiedzi, $z$ tym większym zapałem, kontynuowali zwolennicy króla, jak marszałek nadworny litewski Władysław Gurowski, który podkreślał zasługi Stanisława Augusta już w samym podjęciu spraw, leżacych odłogiem od stu lat ${ }^{20}$. Było to niewatpliwie zgodne $z$ duchem epoki, aczkolwiek niezbyt oryginalne. Dopiero na ostatnim „wolnym" sejmie stanisławowskim z 1786 r. doszło do sformułowania pełniejszej, bardziej uzasadnionej opinii o minionej epoce. Szczególnie zręcznym, bo podbudowanym merytorycznie pochlebstwem wykazał się wówczas poseł kaliski Ignacy Wyssogota Zakrzewski, który m.in. podkreślił, że: „Wydatki dawniej poprzedzały dochody Publiczne, dzisiaj dochody poprzedzaja wydatki, i jeszcze zapas niejaki w skarbie utrzymuja [...] Dziś na Magistratury Narodowe, skargi i zażalenia są, i te czynić wolno, dawniej zaś na prywatne przemocy [...] nie było wolno i sarknąć [...] Słyszę ucisk, znam owszem i klęski pod teraźniejszym, zawsze słodkim W.K. Mci Panowaniem, ale te jeżeli jakie wypadły, nie sa i nie były pierwsze, nie sa i nie były od dawniejszych większe, ale były i sa $z$ nasienia niedostateczności, i słabości poprzedniczych Narodu rządów, które ulepszyć, aby Naród powstał czasu i okoliczności trzeba"21. Podobny też, aczkolwiek bardziej wyważony pod względem oceny saskiej przeszłości, był wywód biskupa smoleńskiego Gabriela Wodzińskiego: „Nie powiem o Pradziadach: My żyjący przed wstapieniem Twoim na Tron Miłościwy Panie [...] mieliśmy takie niemal przekonanie, że ta ziemia, to Królestwo, ta Rzeczypospolita, jest tak nieużyteczną skała; iż się w niej w dochodzie publicznego Skarbu urodzić nic nie może [...] wszyscy pracowali na zysk prywatny, na wygórowanie własnej Fortuny: nic nie myśląc i owszem usuwając się i osoboliwszemi zasłaniajac libertacjami od publicznego dochodu..."22 Te głosy były najbardziej krytyczna oceną saskiej przeszłości, wypowiedziana $\mathrm{w}$ izbach sejmowych, stale przy tym łączona $z$ pochwała panowania Stanisława Augusta, który zyskał poparcie mas szlacheckich

${ }^{20}$ W. G u r o w s k i, Głos... 15 X 1780, [w:] Zbiór mów różnych w czasie Sejmu Sześcioniedzielnego Roku 1780 mianych, Wilno b.d., k. nlb.

${ }^{21}$ I. W y s s o g o t a Z a k r z e w s k i, Głos... 26 X 1786, [w:] Zbiór mów, głosów, przymówień, manifestów etc. mianych na seymie Roku 1786, t. II, Warszawa 1787, s. 490, 492-493. Por. A. Z a h or s ki, Ignacy Wyssogota Zakrzewski, prezydent Warszawy, Warszawa 1963, s. 22-23.

22 [G.] W o d ziń s ki, Mowa... 25 X 1786, [w:] Zbiór mów... 1786, s. 409. 
dzięki odstąpieniu od forsowania reform po niepowodzeniu próby wprowadzenia kodeksu Andrzeja Zamoyskiego ${ }^{23}$.

Ta postawa uwidaczniała się zreszta nie tylko w wypowiedziach sejmowych. Porównania i oceny czasów saskich prezentowane były również przy okazji ważnych uroczystości, podczas których spotykała się elita polityczna Rzeczypospolitej. Tak było np. w czasie pogrzebu generała Andrzeja Mokronowskiego, na którym główną mowę wygłosił Stanisław Kostka Potocki, jeden $z$ filarów opozycji, a jednocześnie Wielki Mówca Wielkiego Wschodu, mówiąc o czasach Augusta III: „Głęboka i szkodliwa dla narodu cisza po gwałtownej nastapiła burzy. Odtąd liczyła Polska te długie nierządnego pokoju lata, w których śmiertelnym uśpiona letargiem, miłego mniemała zażywać spoczynku"24. W sumie ten potępiajacy saska przeszłość nurt wypowiedzi, których liczbę można mnożyć, dominował w okresie rządów Rady Nieustającej. Wówczas elity polityczne - bez względu na swoje powiąania polityczne - stały na stanowisku, że reformowanie państwa w duchu oświeceniowym jest najważniejsze.

Nie znaczy to, by miniona epoka nie budziła pewnych sympatii, nawet $\mathrm{w}$ okresie szczytowej przewagi rządów królewsko-ambasadorskich w Polsce. Przecież to właśnie w latach 1768, 1775 i wreszcie w 1793 przyznano wysokie pensje synom Augusta III. Ponadto tytuł królewiczowej uzyskała Franciszka z Krasińskich 25. Nie były to więc tylko utajone sympatie, lecz konkretne ich wyrazy, pociagajace za sobą wcale poważne obciążenia skarbu, tak usilnie

23 A. S troyn ow ski, Przyczyny odrzucenia kodeksu Andrzeja Zamoyskiego, „Czasopismo Prawno-Historyczne” 1984, t. XXXVI, z. 1, s. 187-198. Por. Ł. K u r d y b a c h a, Dzieje kodeksu Andrzeja Zamoyskiego, Kraków 1951.

24 S.K. Potocki, Mowa przy obchodzeniu pamiatki A. Mokronowskiego, b.m.d., s. 16. Por. B. G r o c h u ls k a, Potocki Stanisław Kostka, [w:] Polski słownik biograficzny [dalej: PSB], t. XXVIII, Wrocław 1985, s. 159. Warto zauważyć, że jednocześnie w Saksonii również zaczęto negatywnie oceniać okres niedawnej unii personalnej z Rzeczapospolitą, co zaowocowało przyjęciem przez Tajną Radę 16 VI 1791 r. stanowiska, że „sukcesja w Polsce nigdy, nawet w najbardziej sprzyjajacych okolicznościach i warunkach nie przysporzy Saksonii korzyści, lecz wręcz przeciwnie przynieść może tylko straty”. R. G ros s, Elektorat saski i jego zwiazki z Polska. Opinie i oceny, [w:] Rzeczpospolita wielu narodów..., s. 61.

25 W. B r a b ców n a, Franciszka z Krasińskich, [w:] PSB, t. VII, Kraków 1948-1958, s. 78-79; R. W o ł o s zy ń s ki, Karol Chrystian Józef, [w:] PSB, t. XII, Wrocław 1966-1967, s. 88-89. 
strzeżonego przez opinię szlachecka, wroga wszelkim pensjom czy gratyfikacjom. Jednak po $1772 \mathrm{r}$. był to już tylko wyraz szacunku dla dynastii, przy jednoczesnej rezygnacji z podnoszenia jej zasług, nawet przez ludzi niechętnych Stanisławowi Augustowi, takich jak chociażby Jędrzej Kitowicz ${ }^{26}$.

Jednocześnie królewska rezygnacja $z$ ambitnych planów reformatorskich przestawała się podobać przedstawicielom młodszego pokolenia. Nie podzielano zwłaszcza wiary w sens polityki umiarkowanego postępu, co szczególnie ujawniało się w konflikcie wokół królewskich planów aukcji wojska do dozwolonej przez mocarstwa rozbiorowe liczby 30 tys. żołnierzy, która uznano za zbyt dużą na potrzeby utrzymania spokoju wewnętrznego i jednocześnie niewystarczajaca dla obrony kraju. Odrzucano tu - jako całkowicie bezzasadna - królewską argumentację, że Saksonia pomyślnie wyszła $z$ okresu upadku i wojennych zawirowań właśnie dzięki posiadaniu takiej właśnie armii27. W tym zakresie wyjątkowa próba propagandowego wykorzystania przez króla wzoru Saksonii okazała się więc chybiona.

Radykalna zmiana w poglądach społecznych - w szczególności elit politycznych - miała nastapić dopiero w trakcie obrad Sejmu Czteroletniego, po odzyskaniu przez Rzeczypospolita możliwości swobodnego działania na arenie międzynarodowej. Wówczas pojawiła się tendencja do zbliżenia $z$ Saksonią i jej dynastia, jako ustosunkowana w monarchicznej Europie. Nie bez wpływu pozostawała tutaj działalność Augusta Essena, dobrze znającego Polaków i chętnie przez nich słuchanego ${ }^{28}$. Jego oddziaływanie na opinie polityczne Polaków było ułatwione ogólnym brakiem rozeznania w sytuacji międzynarodowej i układzie sił politycznych, co tak fatalnie zaciążyło na decyzji Sejmu Czteroletniego o przekazaniu tronu elektorowi saskiemu ${ }^{29}$.

26 Jego sympatię dla przegranego obozu saskiego najlepiej ilustruja opisy zmagań w czasie bezkrólewia po śmierci Augusta III, czy też w okresie konfederacji barskiej. Por. J. Ki t o wi c z, Pamiętniki..., s. 134.

27 I. Krzucki, Głos... 26 X 1778, [w:] Zbiór mów... 1778, k. nlb. Por. A. Stroynowski, Patriotyczne wystapienia opozycji na sejmie 1778 r., „Acta Universitatis Lodziensis", Folia historica 19, 1984, s. 175.

28 L. E n g e s t r ö m, op. cit., s. 152.

29 J. Łoj e k, Geneza i obalenie Konstytucji 3 Maja, Lublin 1986, s. 195-196, 211, 213-218. 
Problem ten zaczą jawić się już w początkach 1788 r., gdy dla przeciwników Rosji zaczęła rysować się możliwość, czy raczej nawet konieczność, osadzenia na tronie polskim przedstawiciela dynastii Wettynów ${ }^{30}$. To zainteresowanie powołaniem na tron elektora saskiego wykazywać mieli zreszta już w 1787 r. nie tylko przeciwnicy rosyjskiej dominacji, czy niechętni samemu Otto Magnusowi Stackelbergowi, jak biskup poznański Antoni Onufry Okęcki, ale nawet ludzie bardzo bliscy ambasadzie carskiej i rosyjskiej orientacji, jak kanclerz Jacek Małachowski ${ }^{31}$. Początkowo jednak zainteresowania Saksonia ograniczały się do rozważania możliwości nawiązania $z$ nią stosunków dyplomatycznych i wysłania tam polskiego ambasadora, co uzasadniano pobytem w Warszawie Essena ${ }^{32}$. Przy tej okazji ujawniły się też zwiastuny zmiany stosunku do saskiej przeszłości, co po raz pierwszy nastapiło w argumentacji posła chełmskiego Wojciecha Suchodolskiego, który potrzebę wysłania poselstwa do Drezna uzasadnił pamięcią saskiego panowania ${ }^{33}$. Jeszcze dobitniej wyraził to kasztelan żarnowski Symeon Szydłowski, który żądanie takie uzasadnił tym, że: „Pod Augustem II rodziłem się, pod III wzrost wziąlem, przeto o Posła do Drezna upraszam"34.

Jednak wśród części posłów - takich jak np. poseł inflancki Julian Ursyn Niemcewicz - czasy saskie nadal nie budziły miłych wspomnień, chociaż wiazali to nie tyle $z$ dynastia, ile raczej $z$ błędami dawnych pokoleń, niewykazujących należytej przezorności i troski o losy kraju, który $z$ tego powodu stał się „postronnych mocarstw Igrzyskiem..."35 Doświadczenia saskiego panowania sta-

30 Dostrzegł to Engeström w swoim liście do Buchholza: „Król ten mógłby być wzięty $z$ domu, który Polacy przeciagiem czasu dłuższego nauczyli się kochać, $z$ domu elektorów saskich”. Por. ibidem, s. 146. Por. też B. D e m b i ń s k i, Polska na przełomie, Lwów 1913, s. 452.

31 H. Ko cój, Elektor saski Fryderyk August III wobec Konstytucji 3 maja, Kraków 1999, s. 9; i d e m, O sukcesje saska, Warszawa 1972, s. 9 (w obydwu powołuje się na depeszę Jana Jakuba Patza z 31 III 1787).

32 Pierwszy w tej sprawie wystapił Walerian Stroynowski. Sesja XXXII dnia 9 XII 1788, Dyaryusz seymu ordynaryinego pod zwiazkiem Konfederacyi Generalney oboyga narodow $w$ Warszawie rozpoczętego roku 1788, wyd. J.P. Łuszczewski, t. I, cz. II, Warszawa 1790 [dalej: Diariusz sejmu 1788], s. 353.

33 „Sześćdziesiątletnie Panowanie warte iest tey od nas attencyi”, Sesja XXXVII dnia 15 XII 1788, Diariusz sejmu 1788, t. I, cz. II, s. 444.

34 Sesja XXXVII dnia 15 XII 1788, Diariusz sejmu 1788, t. I, cz. II, s. 446. Por. H. K o c ój, Polska a Saksonia w czasie sejmu czteroletniego, Kraków 1967, s. 3.

35 Sesja XLVII dnia 9 I 1789, Diariusz sejmu 1788, t. II, cz. I, s. 57. 
wały się nawet przestroga przy podejmowaniu decyzji przez Sejm Czteroletni. Szczególnie sprawa przyznania królowi komendy nad wojskiem wydawała się groźna, co w czasie pamiętnej sesji 3 listopada 1788 r. podnosił poseł inflancki Stanisław Kublicki, przypominając „Dostrzegał Naród niebezpieczeństwa w władzy Królów nad wojskiem, i August II, pokazał ja być niebezpieczna, kiedy podniósł wojnę z Szwedami mniej Rzeczypospolitej wygodna, tylko dla zjednania pomocy do stania się absolutnym jemu tylko samemu użyteczna"36.

Oczywiście pozostawało to $\mathrm{w}$ pewnym przynajmniej zwiąku $z$ tocząca się dyskusją wokół koncepcji ustanowienia w Polsce tronu dziedzicznego, zapoczatkowana wystapieniem Stanisława Staszica $z$ Uwagami nad życiem Jana Zamoyskiego ${ }^{37}$. Z czasem problem sukcesji stał się niezmiernie istotny i $z$ racji powiazania go $z$ koncepcja przekazania następstwa tronu elektorowi saskiemu przyniósł ożywienie tradycyjnych związków ${ }^{38}$. Niewątpliwe jest te $\dot{z}$, że u podłoża wysunięcia kandydatury Fryderyka Augusta III leżała nadzieja na ułatwienie tym starań o przyjęcie zasady tronu dziedzicznego ${ }^{39}$. Przeprowadzenie tej decyzji w sejmie, a głównie łatwiejsze jej zaakceptowanie przez społeczeństwo, miało ułatwić

36 Sesja XII dnia 3 XI 1788, Diariusz sejmu 1788, t. I, cz. I, s. 316.

37 Zagadnienie to najpełniej przedstawia J. Grobis, Republikańskie projekty reformy państwa polskiego $w$ końcu XVIII wieku, „Acta Universitatis Lodziensis", ser. 1, Nauki Humanistyczno-Społeczne, z. 48, 1979, s. 83-96; i d e m, Sukcesja tronu $w$ publicystycznych wypowiedziach Hugona Kołłataja w latach Sejmu Czteroletniego, „Acta Universitatis Lodziensis”, ser. 1, Nauki Humanistyczno-Społeczne”, z. 4, 1976, s. 83-96; i d e m, Czasy saskie..., s. 33-40.

38 Pomijam tu kwestię sensu przyjęcia w $1791 \mathrm{r}$. tego rozwiązania, które wystawiało na ryzyko całe dzieło Sejmu Czteroletniego, szczególnie wobec braku wyraźnego zainteresowania, a głównie zdecydowania samego Fryderyka Augusta III. H. Ko cój, Elektor saski..., s. 7 (tu odwołał się do: E. M a chalski, Sprawa sukcesji saskiej na Sejmie Wielkim, „Kurier Literacko-Naukowy”, 1 V 1939, nr 18, s. 3).

39 Sens takiego rozwiązania zakwestionował Jerzy Łojek: „Sejm polski dokonał reformy ustroju Rzeczypospolitej w duchu monarchicznym w okresie, kiedy sama zasada monarchii poczęła w Europie stawać pod znakiem zapytania [...] Tylko pozornym paradoksem jest stwierdzenie, które chcemy tutaj mocna podkreślić: dawny ustrój Rzeczypospolitej $z$ elekcją królów miał w sobie znacznie większe możliwości potencjalnej ewolucji w kierunku nowoczesnego systemu politycznego wieku XIX niż system monarchii dziedzicznej stworzony przez Konstytucję 3 Maja”. Cyt za: i d e m, op. cit., s. 213-214. 
odwołanie się do opinii szlacheckiej prowincji, $z$ wykorzystaniem wyborów nowego kompletu posłów w czasie sejmików 16 listopada 1790 r. ${ }^{40}$ Spotkało się to $z$ żywym poparciem Kitowicza, który $z$ zadowoleniem odnotował: „Zaleciły więc Stany marszałkom sejmowym, aby przy uniwersałach zwołujacych na sejmiki poselskie przydali listy swoje, imieniem stanów pisane, żeby obywatele [...] na tychże sejmikach w instrukcjach poselskich umieszczali rezolucja sukcesji tronu. A jeżeli ta sukcesja będzie akceptowana jako jedyne dobro kraju i obwarowanie go od wszelkich wewnętrznych i zewnętrznych nieszczęśliwości, aby chcieli zgodzić się na elektora saskiego, pana wielce mądrego i sprawiedliwego, który $z$ wysokich przymiotów swoich znajduje u wszystkich potentatów europejskich wielki szacunek i którego pradziada i dziada panowanie na tronie polskim słodnieje dotychczas w pamięci narodowi"41.

Pomimo ogólnie życzliwego stosunku do Fryderyka Augusta III zwolennikom reform nie udało się osiagnać na tych sejmikach zasadniczego celu, jakim było zyskanie zgody na wprowadzenie tronu dziedzicznego. Co prawda większość opowiedziała się za kandydatura saska, ale tylko na zasadzie wyjątku, często zreszta pod szeregiem dodatkowych warunków. Z zachowanych instrukcji, udzielanych wówczas posłom, kilka można uznać za reprezentatywne dla sposobu myślenia prowincjonalnej szlachty. Najbardziej nieprzejednanie konserwatywne stanowisko zaprezentowano w Ciechanowie, gdzie zastrzeżono nienaruszalność elekcyjności tronu, zgadzajac się jedynie na modyfikację jej formy, tzn. dopuszczając możliwość obioru nowego króla za życia dotychczasowego władcy, przy odsunięciu od prawa do kandydowania przedstawicieli obcych państw, jak też aktualnie panującej familii, co było ciosem

40 W 1790 r. dwukrotnie (8 II i 16 XI) dochodziło do sondowania opinii szlacheckiej prowincji wobec kierunku dokonywanych reform, jak i kwestii elekcji. Okazało się wówczas dowodnie, że sprawa tronu dziedzicznego jest bardzo niepopularna, chociaż i myśl o przekazaniu go elektorowi saskiemu na zasadzie elekcji vivente rege też budziła sprzeciwy, np. na Wołyniu. Por. W. K a li n k a, Sejm Czteroletni, wyd. IV, t. II, Warszawa 1991, s. 390-391; C. N a n k e, Szlachta wołyńska wobec Konstytucji Trzeciego Maja, Lwów 1907, s. 15-18; W. S z c z y g i e 1 s k i, Referendum trzeciomajowe. Sejmiki lutowe 1792 roku, Łódź 1994, s. 231-232; Z. Z i e 1 iń s ka, Sejmiki 8 lutego 1790 - pierwsze referendum na temat dokonań Sejmu, „Wiek Oświecenia”1993, t. IX, s. 114-124.

${ }^{41} \mathrm{~J}$. K it ow i c z, Pamiętniki..., s. 461. Por. J. M i c h a 1 s k i, Konstytucja 3 Maja, Warszawa 1985, s. 38. 
dla króla i Wettynów. Ponadto żądano tam jeszcze utrzymania rozbudowanych pacta conventa ${ }^{42}$. Inne instrukcje $z$ reguły zgadzały się na saskiego kandydata, ale pod warunkiem utrzymania elekcyjności tronu czy nawet przeprowadzenia i tym razem formalnej elekcji, jak tego domagała się szlachta liwska, chociaż czasem jeszcze dodatkowo zastrzegając, że w wypadku rezygnacji elektora wyznaczenie innego kandydata jest niemożliwe - instrukcja sandomierska $^{43}$. Wyjątkowo tylko uznawano cała sprawę za mniej istotna od praw kardynalnych, co wyraźnie stwierdzała instrukcja nurska, tym samym dajac swoim posłom pełną swobodę działania ${ }^{4}$. Niektóre jedynie sejmiki zgadzały się na dowolne ustalenie przez sejm sukcesora Stanisława Augusta (instrukcja czerska) ${ }^{45}$.

Warto $\mathrm{w}$ tym miejscu zauważyć, iż w większości instrukcji nie przytaczano uzasadnienia podjettych decyzji w tak kluczowej sprawie, co prowadzić musi wręcz do znużenia nieomal identycznymi tekstami. W kilku zaledwie wypadkach, aprobujacych elekcje saskiego kandydata na zasadzie wyjątku, dano instrukcjom ciekawsze uzasadnienie, uznając np. za konieczne „głosić wielkie tego Pana przymioty sobie wiadome, pamiętna będac słodkiego tego domu panowania zgadza się chętnie na obranie Jego na Elekta do Tronu"46. Podobnie też pamięcią dawnego panowania uzasadniała swoja zgodę szlachta sochaczewska, która na niepopularna sprawę złamania zasad wolnej elekcji zgodziła się tylko „z powodów wdzięczności szczęśliwie królujących sławnej pamięci przodków jego..."47

42 Instrukcja ciechanowska 16 XI 1790, Teki Pawińskiego nr 1, Biblioteka Polskiej Akademii Umiejętności i Polskiej Akademii Nauk w Krakowie [dalej: BPAU], rkps 8318, k. 365.

43 Instrukcja liwska 16 XI 1790, Teki Pawińskiego nr 5, BPAU, rkps 8322, k. 611. To najbardziej typowe stanowisko oddzielajace sprawę dziedziczenia tronu od powołania elekta saskiego zajął też sejmik lubelski, Instrukcja lubelska 16 XI 1790, Teki Pawińskiego nr 9, BPAU, rkps 8326, k. 486; Instrukcja sandomierska 16 XI 1790, Teki Pawińskiego nr 24, BPAU, rkps 8341, k. 1237. k. 406 .

44 Instrukcja nurska 16 XI 1790, Teki Pawińskiego nr 15, BPAU, rkps 8335,

45 Instrukcja czerska 16 XI 1790, Teki Pawińskiego nr 3, BPAU, rkps 8320, k. 493.

46 Instrukcja łęczycka 16 XI 1790, Teki Pawińskiego nr 30, BPAU, rkps 8330, k. 789 .

47 Instrukcja sochaczewska 16 XI 1790, Teki Pawińskiego nr 30, BPAU, rkps 8347, k. 484. 
Te fragmentaryczne informacje ledwie pozwalaja domyślać się argumentów używanych w czasie sejmikowych debat.

Problem ten przybliżyć moga pamiętniki uczestnika tamtych wydarzeń, którego sukces miał wręcz humorystyczne podłoże, gdyż dla przebycia kordonu wrogów sukcesji musiał przebrać się za stangreta, a już w trakcie obrad okazało się, że jego cała „patetyczna przemowa nie czyni bynajmniej wrażenia, jakiem sobie rokował; widzę wszędzie niesmak wypiętnowany na twarzach, a co najgorzej znudzenie. Jużeż w duszy rozpaczał o pomyślnym skutku mej przemowy, gdy w jednej chwili nasuwa mi się myśl szczególna, że nie powiem pusta, temi słowy przemówić: "Najmilsi panowie i bracia! chciejcie wreszcie zauważyć, że za nieboszczyka Sasa, ojcowie nasi popuszczali pasa". Te $z$ osobliwszego jakowego instynktu wyrzeczone słowa, gdyby iskra elektryczna przebiegły całe grono zebranego tam obywatelstwa i do gruntu przemieniły wszystkich wyobrażenia. Jedne już tylko dochodza mnie głosy $z$ dziwnym zapałem po całej rozbijajace się w izbie: "Niech żyje elektor saski, przyszły król polski». Korzystajac $z$ tak pomyślnej zmiany serc obywatelskich, dobywam $z$ zanadrza przygotowany już akt jednomyślnego zgodzenia się naszych współbraci na tron dziedziczny w rodzinie saskiej i ten licznemi podpisy natychmiast został zapełniony"48.

Przebieg tego właśnie sejmiku, w połączeniu z ułamkową argumentacja cytowanych powyżej instrukcji, pozwala na zdecydowane stwierdzenie, że przeprowadzenie obioru następcy Stanisława Augusta, jeszcze za życia króla, stało się możliwe tylko dzięki wysunięciu kandydatury saskiej49. Aprobata dla elektora saskiego opierała się na nostalgii za czasami spokoju i dobrobytu, łaczonej $z$ nowa nadzieja na uzyskanie poparcia ze strony całego systemu sojuszy, opierających się na pozycji Saksonii i Wettynów. Nikt nie

48 M. C z a c k i, Wspomnienia z roku 1788 po 1792, Poznań 1862, s. 53.

49 Później, już w czasie sejmu grodzieńskiego, od inicjatywy w tej sprawie odcinał się Stanisław August: „Gdy tedy na sejmikach cały naród wyrzekł (prócz jednego Wołynia, które cóżkolwiek wątpliwie odpowiedziało), że żąda widzieć moim następcą Elektora saskiego, już przez to pierwszy krok najważniejszy względem następstwa tronu był uczyniony, nie ode mnie dla narodu, ale od narodu do mnie". Cyt. za: Stan isław August, Głos... 10 VIII 1793, Dyaryusz seymu 1793 roku $w$ Grodnie agitujacego się, [w:] Elity polityczne Polski XVI-XVIII w. Diariusze sejmowe 1764 i 1793, red. J. Wisłocki, Poznań-Kórnik 2001 (wyd. elektroniczne: www.bkpan.poznan. pl/old/elity) - [dalej: Diariusz sejmu 1793], s. 1315. 
znał jednak rzeczywistych poglądów i zamiarów saskiego elektora, co w czasie sejmu grodzieńskiego 1793 r. wytknał poseł lubelski Kazimierz Zaleski, mówiąc: „Ofiarowaliśmy Elektorowi Saskiemu sukcesyą tronu, a gdzież jest jego determinacja, chciałże ją przyjąć?"50

Rzecz przy tym znamienna, że nawet w zmieniajacych się warunkach carskiej interwencji 1792 r., a następnie załamania powstania kościuszkowskiego, sięgano jeszcze po saską kartę, a przynajmniej myślano o jej użyciu. Tym razem jednak nie miał to być już sam elektor, lecz jego córka Maria Augusta Nepomucena. Ona to w zamiarach Stanisława Augusta miała stać się przynętą dla rosyjskiego dworu, gdyż dzięki małżeństwu $z$ w. ks. Konstantym miała zapoczątkować nową dynastię, przynieść zarazem ratunek Rzeczypospolitej, jak i przedłużyć władzę ostatniego monarchy51. Jest to już jednak osobny temat.

Kończąc te rozważania należy podkreślić wyraźny, wręcz oczywisty związek prezentowanych na forum publicznym ocen $z$ bieżąca sytuacja polityczna. O ile w pierwszych latach panowania Stanisława Augusta dochodziło do stałego ścierania się odmiennych opisów saskiej rzeczywistości, wynikających $z$ ostrej walki dwóch obozów politycznych w czasie elekcji, a następnie kolejnych konfederacji (radomskiej i barskiej), o tyle w późniejszych latach doszło do wyraźnej unifikacji prezentowanych opinii. Powszechne dażenie do zabezpieczenia dalszego bytu Rzeczypospolitej zmuszało do podejmowania ograniczonych reform administracyjnych, skarbowych, wojskowych i oświatowych. Poparcie dla nich prowincji szlacheckiej starano się uzyskać poprzez obciążanie wina za rozbiór i zacofanie kraju saskiego panowania, co wyrażało się w zdecydowanej, często przesadnej czy nawet zafałszowanej krytyce ze strony oświeconych elit, wypowiadanej na forum publicznym. Dopiero od momentu zaistnienia możliwości dokonania prawdziwego zwrotu politycznego w czasie obrad Sejmu Czteroletniego mogła nastapić zmiana treści tych ocen. $Z$ nagła czasy saskie zaczęto oceniać pozytywnie lub nawet je gloryfikować, ponieważ konieczne stało się zjednoczenie społeczeństwa pod hasłami patriotyzmu i niepodległościowych

50 [K.] Z a le s ki, Głos... 3 VII 1793, [w:] Diariusz sejmu 1793, s. 1020.

$51 \mathrm{Z}$ nierealności tych koncepcji zdawano sobie sprawę nawet na prowincji. Por. J. Kit ow i c z, Pamiętniki..., s. 622. 
reform, których gwarantem miał być właśnie elektor saski. W tych warunkach niedawni krytycy panowania saskiego dostrzegli jego powab ${ }^{52}$. Jednak już wkrótce, w czasie targowickiej reakcji i sejmu grodzieńskiego, gdy trzeba było szukać możliwości dalszego istnienia okrojonej Rzeczypospolitej pod rosyjska protekcja, ponownie trzeba było negatywnie spojrzeć na czasy saskie. Wszystkie te gwałtowne zmiany wspomnianych ocen dotyczyły jednak tylko wypowiedzi oficjalnych, wyrażanych publicznie. Prywatnie zaś, głównie w pamiętnikach, dobrze wspominano czasy młodości, zamożności i niezależności kraju, ale te poglądy - przekazywane także młodszemu pokoleniu - były raczej wstydliwie ukrywane, chociaż niewątpliwie ułatwily aprobatę dla reform Sejmu Czteroletniego i sukcesji saskiej w $1791 \mathrm{r}$.

52 Dotyczyło to również oceny Karola Stanisława Radziwiłła, który wcześniej był wyśmiewany jako symbol braków saskiego wychowania, by w czasie Sejmu Czteroletniego nagle stać się wyrazicielem najlepszych tradycji narodu i patriotyzmu, co widać wyraźnie chociażby w pamiętnikach Niemcewicza. Por. J.U. N i e m c e w i c z, op. cit., t. I, s. 122-123, 300. 